\title{
Anti-Inflammatory Effects of a Polyphenols-Rich Extract from Tea (Camellia sinensis) Flowers in Acute and Chronic Mice Models
}

\author{
Bang-Tian Chen, ${ }^{1}$ Wei-Xi Li, ${ }^{1}$ Rong-Rong He, ${ }^{1,2}$ Yi-Fang Li, ${ }^{1}$ \\ Bun Tsoi, ${ }^{1}$ Yu-Jia Zhai, ${ }^{1}$ and Hiroshi Kurihara ${ }^{1}$ \\ ${ }^{1}$ Institute of Traditional Chinese Medicine and Natural Products, Jinan University, Guangzhou 510632, China \\ ${ }^{2}$ State Key Laboratory of Drug Research, Shanghai Institure of Materia Medica, Chinese Academy of Sciences, Shanghai 201203, China
}

Correspondence should be addressed to Rong-Rong He, rongronghe66@163.com

and Hiroshi Kurihara, hiroshi_kurihara@163.com

Received 25 May 2012; Accepted 18 June 2012

Academic Editor: Felipe Dal-Pizzol

Copyright (C) 2012 Bang-Tian Chen et al. This is an open access article distributed under the Creative Commons Attribution License, which permits unrestricted use, distribution, and reproduction in any medium, provided the original work is properly cited.

While beneficial health properties of tea leaves have been extensively studied, less attention is paid to the flowers of tea. In this study, the anti-inflammatory effects of hot water extract of tea (Camellia sinensis) flowers were investigated. Pharmacological studies found that administration of tea flowers extract (TFE) could effectively inhibit croton oil-induced ear edema and carrageenininduced paw edema. Furthermore, administration of TFE also protected against Propionibacterium acnes $(P$. ances) plus lipopolysaccharide-(LPS-) induced liver inflammation by reversing the histologic damage and plasma alanine aminotransferase (ALT) increase. Moreover, the levels of nitric oxide (NO), tumor necrosis factor-(TNF)- $\alpha$ and interleukin-(IL-) $1 \beta$ mRNA in mouse liver were markedly suppressed after treatment with TFE in mice with immunological liver inflammation. These results indicated that tea flowers had potent anti-inflammatory effects on acute and immunological inflammation in vivo, and may be used as a functional natural food.

\section{Introduction}

Tea (Camellia sinensis) is one of the most widely consumed beverages in the world, which contains a large quantity of polyphenols and alkaloids. The unique flavor of tea is contributed by its characteristic polyphenol compounds. Together with phenolic acids such as gallic acid, polyphenols are constituting up to $30 \%$ of the dry weight of tea leaves [1]. During the past decades, numerous in vitro and in vivo studies have suggested the biological properties of tea and tea polyphenols in cancer, cardiovascular disease, antioxidant, anti-inflammatory, antiobesity, and neurodegenerative disorders [2-7]. Therefore, polyphenol content has been considered as an important chemical parameter for tea quality regarding its biological property.

In our daily life, we enjoy the delightful tea beverages prepared from the leaf buds. There are also several kinds of flower teas in the markets, namely, jasmine, cinnamon, rose, lotus, and chrysanthemum flower teas, which are made from tea leaves and different species of flowers [8]. Interestingly, less attention has been given to flower of tea (Camellia sinensis). In fact, tea flower, as well as tea, has been considered a healthful beverage since ancient times, especially in southern China. Tea flower possess a pleasant bitter taste which persist in the mouth after drinking. It has also been considered and widely used as a folk herb to treat a variety of inflammatory diseases for several centuries. However, less pharmacological studies have been carried out on this herbal medicine. Previous study have demonstrated that tea flower extracts exhibited strong hydroxyl radical scavenging effects in the Fenton reaction system and nitric oxide suppressing effects in LPS-induced Raw 264.7 cells [8]. It was also reported that water extract of tea flowers had potent bioactivity against human breast cancer MCF7 cells in vitro [9]. Tea flower showed strong antioxidant effects, however, scavenging of free radicals may not be the sole mechanism by which tea-derived polyphenols exert their protective effects. It is noteworthy that most reports on the 
beneficial effects of tea flowers have been obtained from in vitro studies and more detailed investigations are required to explore in vivo situations. The purpose of this study was to determine the polyphenols content in tea flower. In addition, we also examine the anti-inflammatory effect of a crude tea flower extract on acute inflammation and P. acnes plus LPSinduced liver inflammation in mice.

\section{Materials and Methods}

2.1. Materials and Preparation of Tea Flowers Extract (TFE). Gallic acid (GA), (-)-epicatechin gallate (ECG), (-)-epicatechin (EC), (-)-gallocatechin gallate (GCG), (-)-epigallocatechin (EGC), and (-)-epigallocatechin gallate (EGCG) were purchased from Wako Pure Chemical Ind. (Osaka, Japan). Myricetin, quercetin, kaempferol, croton oil, carrageenin, Evans blue, Cyclosporin A (Cs A), dexamethasone acetate (DEX), and LPS from Escherichia coli 055:B5 were purchased from Sigma Chemical Co. (St. Louis, Mo, USA). $P$. acnes (ATCC6919) used in this study had previously been prepared by our laboratory.

Tea flowers were procured from Guangdong Tea Experiment Substation, Yingde, Guangdong, China. Dried tea flowers were treated with 20 parts of boiling water for $5 \mathrm{~min}$. After filtration and evaporation of water, the residue was powdered under frozen decompression. The recovery rate was $19.5 \%$. The extract residue was immediately dissolved in water before the experiment.

2.2. Polyphenol Compounds Analysis of Tea Flowers. The concentrations of tea catechins in tea flower buds was determined by HPLC under the following conditions: Cosmosil 5PE-MS column (Nakalai Tesuque, Kyoto, Japan, $4.6 \mathrm{~mm} \times$ $150 \mathrm{~mm}, 5 \mu \mathrm{m}$ ); mobile phase, eluent A $0.05 \%$ trifluoroacetic acid (TFA) in water; eluent B $0.05 \%$ TFA in acetonitrile; flow rate, $2 \mathrm{~mL} / \mathrm{min}$; column temperature, $40^{\circ} \mathrm{C}$; detection wavelength of $280 \mathrm{~nm}$. The analysis was performed with a gradient program of $10 \%$ eluent B for $5 \mathrm{~min}, 21 \%$ for $8 \mathrm{~min}$, and $90 \%$ for $6 \mathrm{~min} \mathrm{[10].} \mathrm{The} \mathrm{quantification} \mathrm{of} \mathrm{individual}$ catechins was determined by standard calibration curves calculated from those of authentic reference standards. The total flavonoid content was determined using a colorimetric method as described by $\mathrm{Wu}$ et al. [11]. As shown in Table 1, EGCG, ECG, were identified as major polyphenol constituents of tea flower, while GCG and GA were present in smaller quantities. The total catechins and flavonoid contents in tea flowers were 37.46 and $11.61 \mathrm{mg} / \mathrm{g}$, respectively. All the analyses have been performed in triplicate and the results are reported on wet basis.

2.3. Experimental Animals. Eight-week-old male KM mice were purchased from the Guangdong Medical Laboratory Animal Center (Guangzhou, China). All mice were kept in a pathogen-free animal room under controlled conditions at $23 \pm 1^{\circ} \mathrm{C}$. A $12 \mathrm{~h}$ light-dark cycle was maintained, with lights on from the time of 06:00 to 18:00. The mice were provided with standard laboratory diet and water. The animals were allowed to acclimatize to the environment for 1 week before
TABLE 1: Amounts of polyphenols in water extract of tea flowers.

\begin{tabular}{lc}
\hline Compounds & $\mathrm{mg} / \mathrm{g}$ of tea flowers \\
\hline EGCG & 15.45 \\
EC & 4.07 \\
GCG & 0.43 \\
ECG & 11.10 \\
EGC & 5.08 \\
GA & 1.33 \\
\hline Total flavonoid content & 11.61 \\
\hline
\end{tabular}

the experiment. Procedures for animal experiments were conducted in accordance with the Guiding Principles for the Care and Use of Laboratory Animals as adopted and promulgated by the United States National Institutes of Health.

\subsection{Croton Oil-Induced Edema and Capillary Permeability in} Mice Ear. The croton oil ear test was performed according to $[12,13]$. A total of $25 \mu \mathrm{L}$ of $0.3 \%$ croton oil (dissolved in acetone) was topically applied to the inner surface of the right ear of each mouse. DEX ( $1 \mathrm{mg} / \mathrm{kg}$, served as positive control) and TFE (50 mg/kg, $100 \mathrm{mg} / \mathrm{kg}$, and $200 \mathrm{mg} / \mathrm{kg}$ ) were orally administered to mice $30 \mathrm{~min}$ prior to the application of croton oil. The left ear remained untreated as negative control. Three hours after croton oil being applied, 1\% Evans blue (dissolved in saline) was injected via the tail vein at a dose of $10 \mathrm{~mL} / \mathrm{kg}$ body weight. The animals were sacrificed $1 \mathrm{~h}$ later and both the treated and untreated ears were collected for further determination. The ears were soaked in $1 \mathrm{~mL}$ of $1 \mathrm{M} \mathrm{KOH}$ at $37^{\circ} \mathrm{C}$ for $24 \mathrm{~h}$ and $9 \mathrm{~mL} 0.6 \mathrm{M} \mathrm{H}_{3} \mathrm{PO}_{4}-$ acetone $(5: 13)$ was added afterwards. The mixture was then centrifuged at $3000 \mathrm{rpm}$ for $15 \mathrm{~min}$. The absorbance of supernatants was detected at $620 \mathrm{~nm} \mathrm{[12].} \mathrm{The} \mathrm{quantification}$ of Evans blue in mice ear, as a major indicator of capillary permeability was determined by standard calibration curves.

2.5. Carrageenan-Induced Paw Edema in Mice. The carrageenan-induced paw edema model in mice was used to study the effect of TFE on acute inflammation [14]. Mice were treated with DEX ( $1 \mathrm{mg} / \mathrm{kg}$, served as positive control), TFE $(50 \mathrm{mg} / \mathrm{kg}, 100 \mathrm{mg} / \mathrm{kg}$, and $200 \mathrm{mg} / \mathrm{kg}$ ) or the same volume of saline by oral administration. After $30 \mathrm{~min}$, edema was induced by injecting $10 \mu \mathrm{L}$ of carrageenan $(2.0 \%, \mathrm{w} / \mathrm{v})$ into subplantar area of the right hind paw. Measurement of paw size was carried out with caliper rule (Digimatic, Mitutoyo 500, Japan) $4 \mathrm{~h}$ following carrageenan injection. The extent of the edema was measured by the difference in size between the two hind paws.

2.6. P. acnes Plus LPS-Induced Immunological Liver Inflammation. TFE $(50 \mathrm{mg} / \mathrm{kg}, 100 \mathrm{mg} / \mathrm{kg}$, and $200 \mathrm{mg} / \mathrm{kg})$ and Cs A $(25 \mathrm{mg} / \mathrm{kg}$, served as positive control) were orally administrated to mice for 7 days, while the normal control group and model group received saline only. Liver inflammation was induced by injecting heat-killed $P$. acnes in saline $(0.2 \mathrm{mg} / 10 \mathrm{~g}$ body weight) via the tail vein $2 \mathrm{~d}$ after TFE, Cs A 
and saline administration. On the seventh day, LPS ( $5 \mu \mathrm{g} / 10 \mathrm{~g}$ weight) was injected to all mice intravenously except normal control group. The animals were sacrificed under anesthesia with diethyl ether for liver inflammation analysis $5 \mathrm{~h}$ after LPS injection [15]. Blood samples were taken from the hearts of the mice and transferred into a tube containing $2 \%$ sodium heparin. The tubes were centrifuged at $5000 \mathrm{rpm}$ for $5 \mathrm{~min}$ and supernatants were used for following experiment. Plasma alanine aminotransferase (ALT) activity, which is a marker of hepatocyte injury, was determined by using commercial kits and absorbance was detected with MK3 microplate reader (Labsystems Co., Finland) at $492 \mathrm{~nm}$.

2.7. Histological Analysis. For histologic analysis, small sections of fresh liver tissues were immediately fixed in $10 \%$ buffered formalin and embedded in paraffin wax. Tissue sections $(4 \mu \mathrm{m})$ were stained with haematoxylin and eosin $(\mathrm{H} \& \mathrm{E})$ and were examined for liver damage under light microscopy.

2.8. Determination of Nitric Oxide (NO) Production. NO concentration in liver tissue was determined by the Griess reaction [16]. Briefly, liver tissues were homogenated in saline, a $40 \mu \mathrm{L} 20 \%$ liver homogenate sample was transferred into 96-well microplates, and then $160 \mu \mathrm{L}$ Griess reagent ( $1 \%$ sulfanilamide in $5 \% \mathrm{H}_{3} \mathrm{PO}_{4}$ and $0.1 \% \mathrm{~N}$ - $(1$ naphthyl) ethylenediamine dihydrochloride) was added. The absorbance of the chromophore was read at $540 \mathrm{~nm}$. A standard curve was constructed using known concentrations of sodium nitrite [17].

2.9. RNA Extraction and Reverse Transcription-Polymerase Chain Reaction (RT-PCR). Total RNA was extracted from the liver samples by using Trizol Reagent according to the protocol of the manufacturer (Invitrogen, Carlsbad, CA, USA). The concentration of the extracted RNA was calculated by measuring the optical density at $260 \mathrm{~nm}$. Aliquots of $2 \mu \mathrm{g}$ RNA were transformed to first strand complementary DNA (cDNA) at $42^{\circ} \mathrm{C}$ for $1 \mathrm{~h}$ in a $20 \mu \mathrm{L}$ reaction mixture containing mouse Moloney leukemia virus reverse transcriptase (Invitrogen, CA, USA) with oligo $(\mathrm{dT})_{15}$ primers (Tiangen, Beijing, China). PCR amplification was carried out with $1 \mu \mathrm{L}$ of the resulting cDNA, $12.5 \mu \mathrm{L}$ of $2 \times$ Taq reaction buffer (Tiangen, Beijing, China), $2 \mu \mathrm{L}$ of dNTP mixture, $1 \mu \mathrm{M}$ forward primer, $1 \mu \mathrm{M}$ reverse primer, and $1 \mu \mathrm{L}$ of Taq polymerase (Tiangen, Beijing) in a total volume of $25 \mu \mathrm{L}$. The PCR primers for mouse TNF- $\alpha$ (forward, 5'-GGCGGTGCCTATGTCTC-3'; reverse, $5^{\prime}$-GCAGCCTTGTCCCTTGA-3'), IL- $1 \beta$ (forward, $5^{\prime}$-GCTGGAGAGTGTGGAT- $3^{\prime}$; reverse, $5^{\prime}$-CTTGTGAGGTGCTGATG- $3^{\prime}$ ), $\beta$-actin (forward, $5^{\prime}$-ACCCAGATCATGTTTGAGACC- $3^{\prime}$; reverse, $5^{\prime}$-CATACCCAAGAAGGAAGGCT- $\left.3^{\prime}\right)$ were used. The thermocycler conditions were $94^{\circ} \mathrm{C}$ for $30 \mathrm{~s}$, with an annealing temperature of $60^{\circ} \mathrm{C}$ for $40 \mathrm{~s}$ and an elongation temperature of $72^{\circ} \mathrm{C}$ for $50 \mathrm{~s}$ for the first 30 cycles, followed by an elongation temperature of $72^{\circ} \mathrm{C}$ for $7 \mathrm{~min}$. After the reaction was completed, the amplified product was removed from the tubes and run on $2 \%$ agarose
TABLE 2: Effects of TFE on croton oil-induced ear edema and capillary permeability in mice ${ }^{\mathrm{a}}$.

\begin{tabular}{lccc}
\hline Group & Dose $(\mathrm{mg} / \mathrm{kg})$ & Edema degree $(\mathrm{mg})$ & Evans blue $(\mu \mathrm{g} / \mathrm{ear})$ \\
\hline control & - & $21.93 \pm 2.32$ & $3.86 \pm 0.37$ \\
& 50 & $20.69 \pm 3.16$ & $3.72 \pm 0.34$ \\
TFE & 100 & $19.07 \pm 2.04^{\mathrm{b}}$ & $3.02 \pm 0.26^{\mathrm{c}}$ \\
& 200 & $16.36 \pm 1.42^{\mathrm{c}}$ & $2.89 \pm 0.29^{\mathrm{c}}$ \\
DEX & 1 & $2.02 \pm 0.57^{\mathrm{c}}$ & $0.38 \pm 0.24^{\mathrm{c}}$ \\
\hline
\end{tabular}

${ }^{a}$ Values are mean \pm S.D. of differences in weight between right and left ear of mice $(n=10)$. ${ }^{b}$ Significantly different from the control mice at $P<0.05$. ${ }^{c}$ Significantly different from the control mice at $P<0.01$.

gel and visualized by ethidium bromide staining. The band intensity of ethidium bromide fluorescence was measured using an image analysis system (Bio-Rad, Hercules, CA, USA), then quantified with Quantity One analysis software (Bio-Rad, Hercules, CA, USA), and expressed as the ratio to $\beta$-actin.

2.10. Statistical Analysis. The data were presented as mean \pm S.D. and analyzed statistically by one-way analysis of variance (ANOVA) followed by Dunnett's significant post-hoc test for pair-wise multiple comparisons. Differences in data of biochemical parameters among the different groups were considered to be statistically significant at $P<0.05$.

\section{Results}

3.1. Effects of TFE on Croton Oil-Induced Ear Edema and Capillary Permeability in Mice. Topical application of croton oil-induced edema at the ears of mice and significant increase in the weight of treated right ear when compared with the untreated left ear. As shown in Table 2, the oral administration of TFE produced a dose-dependent suppression of ear edema in mice. The edema inhibitory rates of TFE were $5.65 \%, 13.04 \%$, and $25.40 \%$ at the dose of 50,100 , and $200 \mathrm{mg} / \mathrm{kg}$, respectively. Whereas DEX ( $1 \mathrm{mg} / \mathrm{kg}$ ) gave rise to a significant inhibition of $90.79 \%$ in ear weight compared to control. Croton oil-induced capillary permeability leaded to the increase of Evans blue leakage in the mice ear. TFE at doses of 100 and $200 \mathrm{mg} / \mathrm{kg}$ showed significant inhibitory effects on croton oil-induced capillary permeability (Table 2), with $21.76 \%$ and $25.13 \%$ inhibition of dye leakage at doses of $100 \mathrm{mg} / \mathrm{kg}$ and $200 \mathrm{mg} / \mathrm{kg}$, respectively. DEX $(1 \mathrm{mg} / \mathrm{kg})$ gave a significant inhibition of dye leakage at $90.16 \%$.

3.2. Effect of TFE on Carrageenan-Induced Paw Edema in Mice. In the carrageenan-induced edema test, the paw sizes and percentages of inhibition by TFE and DEX are shown in Table 3. A maximum increase of paw thickness, $1.22 \pm$ $0.15 \mathrm{~mm}$, was obtained $4 \mathrm{~h}$ following carrageenan injection in control mice. TFE significantly decreased the carrageenaninduced edema at doses of $200 \mathrm{mg} / \mathrm{kg}$ and achieved its maximal inhibitory effects of $19.67 \%$. At a dose of $1 \mathrm{mg} / \mathrm{kg}$, DEX produced a greater inhibition of edema by $69.67 \%$. 


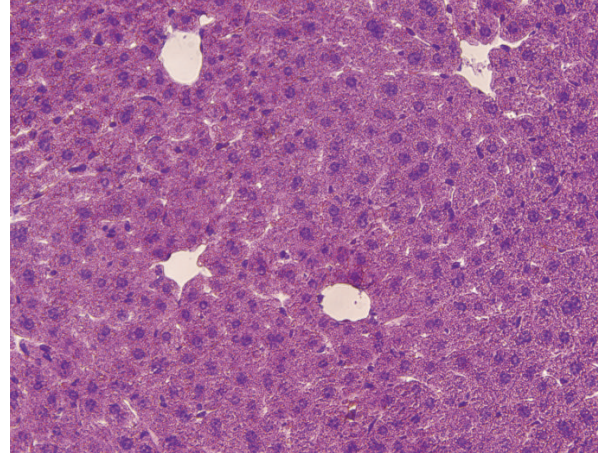

(a)

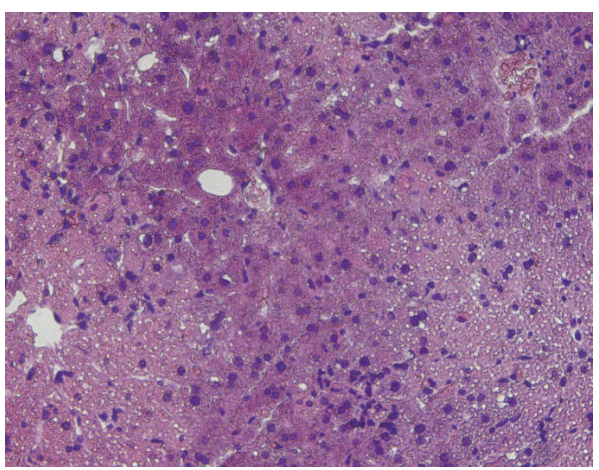

(c)

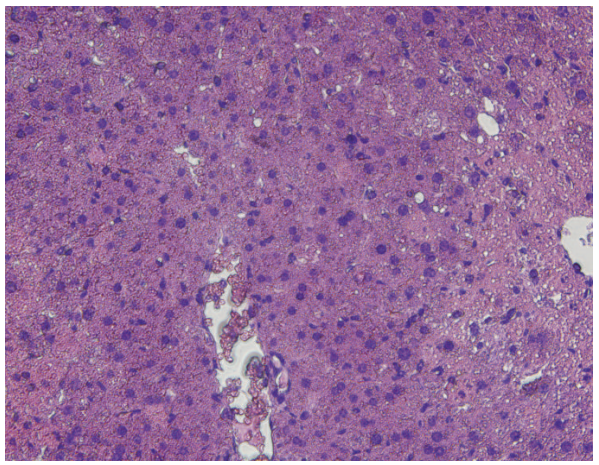

(e)

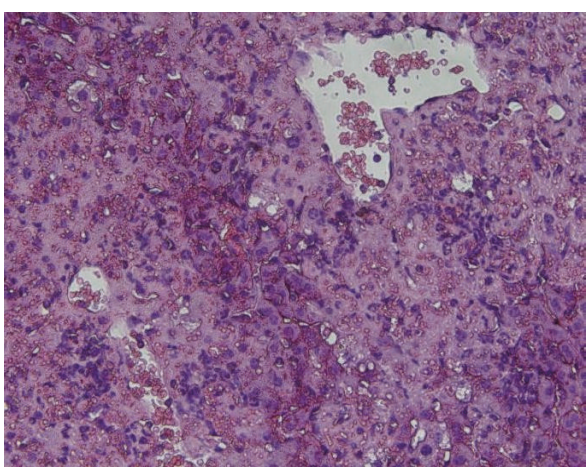

(b)

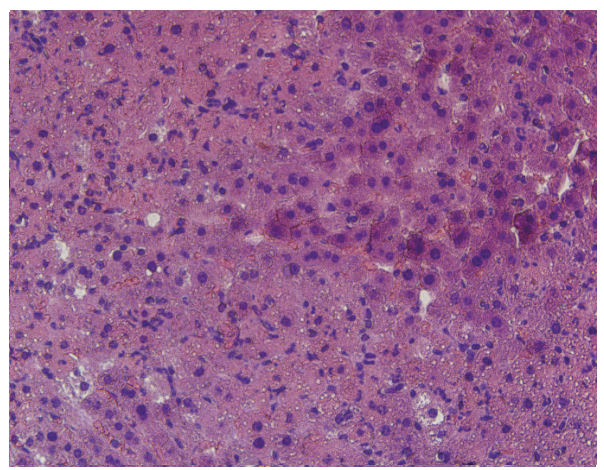

(d)

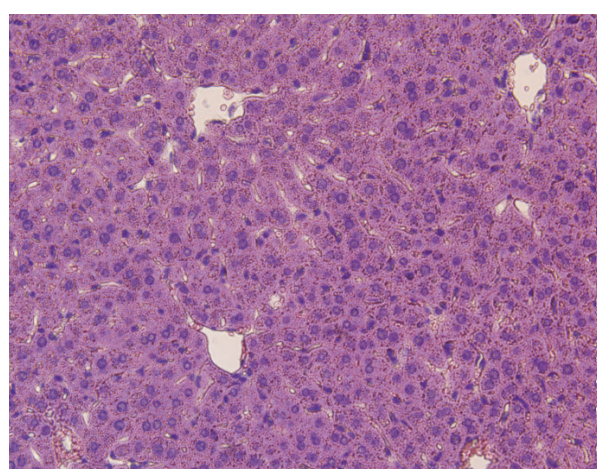

(f)

FIgURE 1: Effects of TFE on histological manifestation in P. acnes plus LPS-induced liver inflammation. Hematoxylin and eosin staining images of representative liver tissue sections were shown at the same magnification $(200 \times)$. (a) Normal control, (b) liver inflammation model, (c) TFE $50 \mathrm{mg} / \mathrm{kg}$, (d) TFE $100 \mathrm{mg} / \mathrm{kg}$, (e) TFE $200 \mathrm{mg} / \mathrm{kg}$, and (f) Cs A $25 \mathrm{mg} / \mathrm{kg}$.

TABLE 3: Effect of TFE on carrageenan-induced paw edema in mice ${ }^{\mathrm{a}}$.

\begin{tabular}{lccc}
\hline Group & Dose $(\mathrm{mg} / \mathrm{kg})$ & Paw thickness $(\mathrm{mm})$ & Inhibitory rate $(\%)$ \\
\hline control & - & $1.22 \pm 0.15$ & - \\
& 50 & $1.16 \pm 0.24$ & 4.92 \\
TFE & 100 & $1.07 \pm 0.23$ & 12.30 \\
& 200 & $0.98 \pm 0.20^{\mathrm{b}}$ & 19.67 \\
DEX & 1 & $0.37 \pm 0.13^{\mathrm{b}}$ & 69.67 \\
\hline
\end{tabular}

aalues are mean \pm S.D. of differences in thickness between right and left hind paw of mice $(n=10)$. ${ }^{\mathrm{b}}$ Significantly different from the control mice at $P<0.01$.
3.3. Effects of TFE on P. acnes Plus LPS-Induced Liver Inflammation. The effect of TFE on P. acnes plus LPS-induced liver inflammation was investigated by the histologic analysis and plasma ALT level. As shown in Figure 1, there was no obvious pathological abnormality in normal control group, liver parenchyma was in good morphology and hepatocytes were arranged around the central vein, no congestion and inflammation were observed in the sinusoids (Figure 1(a)). Compared with normal mice, liver tissue sections from $P$. acnes plus LPS challenged mice showed severe pathological alterations, such as confusion of hepatic lobule structure with inflammatory cell infiltration, serious vacuolation of hepatic 


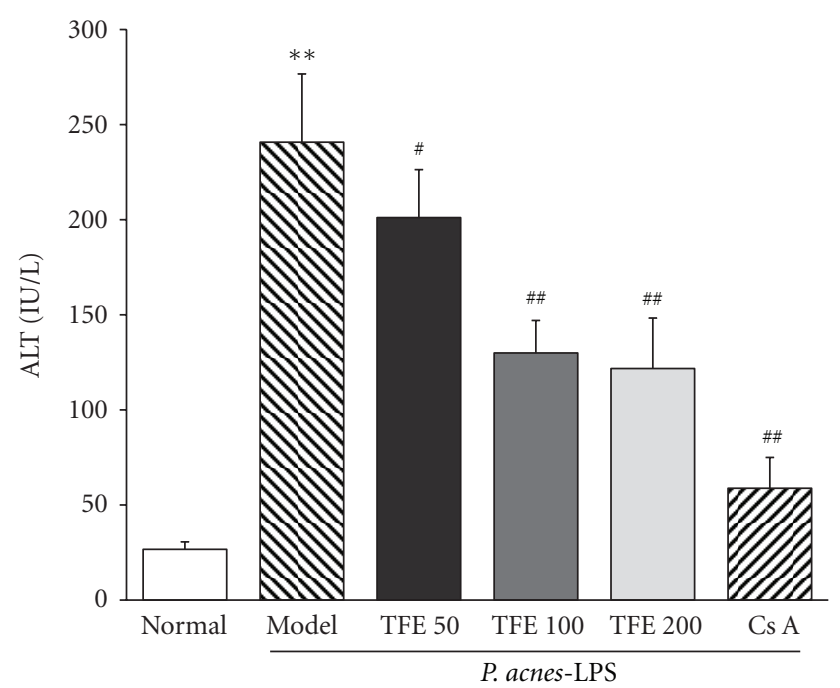

FIGURE 2: Effects of TFE on plasma ALT activity in mice treated with $P$. acnes plus LPS. Mice were treated with TFE, Cs A or saline for 7 days. Liver inflammation was induced by $P$. acnes and LPS injected intravenously on the 2nd and 7th day of TFE administration. The results represented mean \pm S.D. of values obtained from 7 mice in each group, with significance showed as $* * P<0.01$ compared with normal group and ${ }^{\#} P<0.05$ and ${ }^{\# \#} P<0.01$ compared with model group.

cells, necrosis and erythrocyte influx (Figure 1(b)). However, in TFE $(50,100$, and $200 \mathrm{mg} / \mathrm{kg})$ treated groups and Cs A group, the area and extent of necrosis were attenuated and the immigration of inflammatory cells was reduced (Figures $1(\mathrm{c})-1(\mathrm{f}))$. As shown in Figure 2, plasma ALT activity in $P$. acnes plus LPS-treated mice was significantly higher than the normal group $(P<0.01)$. TFE significantly reversed the ALT activity by $16.49 \%, 46.05 \%$, and $49.42 \%$ at doses of $50 \mathrm{mg} / \mathrm{kg}, 100 \mathrm{mg} / \mathrm{kg}$, and $200 \mathrm{mg} / \mathrm{kg}$, respectively. These data indicate that TFE attenuates liver inflammation induced by $P$. acnes plus LPS injection.

\subsection{Effects of TFE on NO Production in P. acnes Plus LPS Treated Mice. NO is a common inflammatory mediator involved in the pathogenesis of inflammation. In this study, the effect of TFE on P. acnes plus LPS induced liver inflamma- tion was also investigated by determining the NO production in liver tissues. As shown in Figure 3, compared with the normal control mice, the concentration of NO was markedly increased in model group $(P<0.01)$. However, significant concentration-dependent inhibition of NO production was detected when mice were treated with TFE $(100,200 \mathrm{mg} / \mathrm{kg})$, with inhibitory of $28.6 \%$ and $34.9 \%$, respectively.}

3.5. Effects of TFE on TNF- $\alpha$ and IL-1 $\beta$ mRNA Expression. To further explore the mechanisms of the protective effects of TFE on immunological liver inflammation induced by $P$. acnes and LPS, mRNA expression of TNF- $\alpha$ and IL- $1 \beta$ mRNA in liver tissue were determined. Compared with the normal control group, treatment with $P$. acnes and LPS led to significant increases in TNF- $\alpha$ and IL- $1 \beta$ mRNA levels

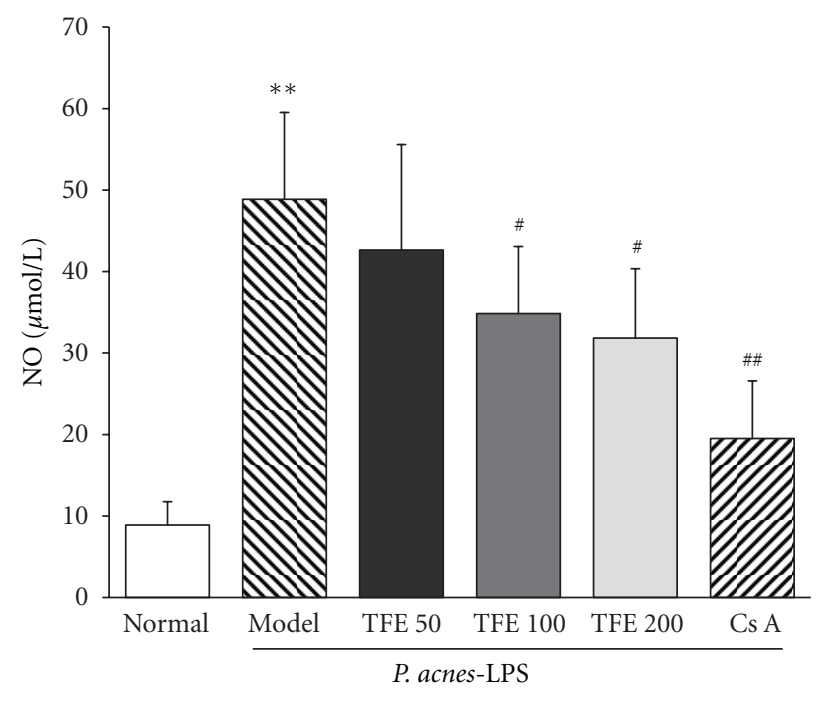

FIGURE 3: Effects of TFE on NO production in livers of mice treated with $P$. acnes plus LPS. The results represented mean \pm S.D. of values obtained from 7 mice in each group, with significance showed as ${ }^{* *} P<0.01$ compared with normal group and ${ }^{\#} P<0.05$ and ${ }^{\# \#} P<$ 0.01 compared with model group.

(Figure 4). However, this effect was reversed in mice treated with $\operatorname{TFE}(50,100$, and $200 \mathrm{mg} / \mathrm{kg}$ ), with similar result from mice treated with Cs A.

\section{Discussion}

Several experimental and epidemiological studies have related tea consumption with various biological and pharmacological functions $[18,19]$. It is believed that the health benefit of tea are mainly attributed to its antioxidant properties and the ability of its polyphenolic catechins to scavenge reactive oxygen species [20]. In this study, the contents of six catechins, namely, EGCG, EC, GCG, ECG, EGC, and GA, in tea flowers were detected using HPLC. In addition, total flavonoid content was determined; flavonols were reported to contribute importantly to antioxidant activity and the color of tea [21]. The present study demonstrated that tea flowers contain appreciable amounts of polyphenols. These results indicated that tea flowers might exhibit beneficial health properties and might be suitable for making an alternative to tea beverage.

In this study, the anti-inflammatory effects of TFE were evaluated by various approaches in mice model. Ear edema induced by croton oil has been widely accepted as a useful pharmacological model for the investigation of new anti-inflammatory drugs [22]. Croton oil contains 12-Otetradecanoylphorbol-13-acetate (TPA) and other phorbol esters as main irritant agents [23]. Application of croton oil can induce significant inflammatory responses as characterized by edema, neutrophil infiltration, prostaglandins production, and increases in vascular permeability [24]. It is reported that cyclooxygenase inhibitors, 5-lipoxygenase inhibitors are highly effective against inflammation caused by TPA [25]. Polyphenols have already been recognized 


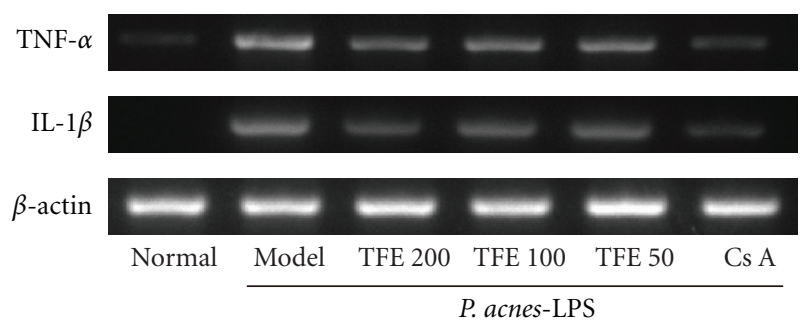

(a)

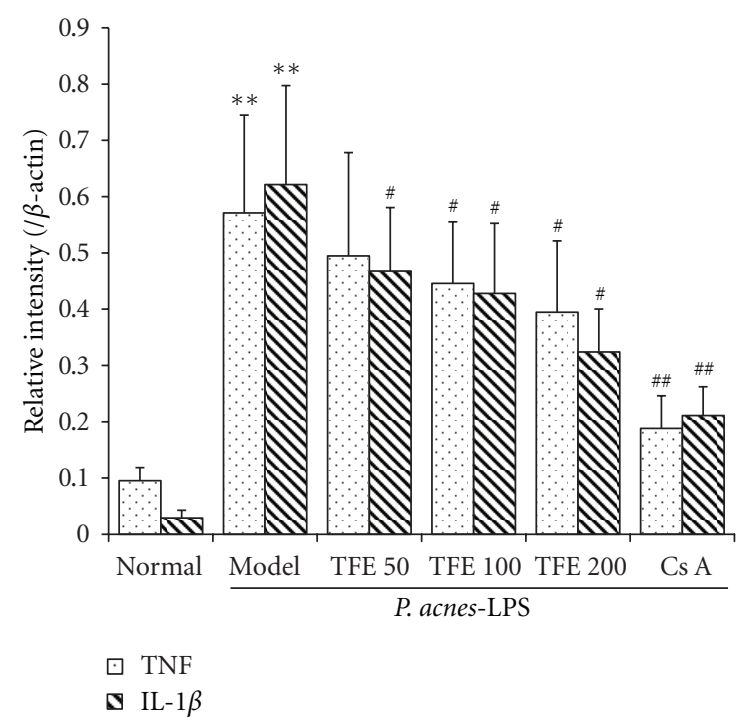

(b)

Figure 4: Effects of TFE on TNF- $\alpha$ and IL- $1 \beta$ mRNA expression. (a) Agarose gel electrophoresis of RT-PCR amplification of TNF- $\alpha$, IL$1 \beta$ and $\beta$-actin mRNA. (b) Densitometric analysis of PCR products of TNF- $\alpha$ and IL- $1 \beta$ mRNA. The results represented mean \pm S.D. of values obtained from 7 mice in each group, with significance showed as ${ }^{* *} P<0.01$ compared with normal group and ${ }^{*} P<0.05$ and ${ }^{\# \#} P<0.01$ compared with model group.

as potent inhibitors of cyclooxygenase and lipoxygenase in different studies [26-28]. Thus, results obtained in this research suggested that TFE may have similar pharmacological properties with those of cyclooxygenase and lipoxygenase inhibitors, which might be related to the containing polyphenols. Carrageenan-induced paw edema assay was also carried out to estimate the effect of TFE on acute inflammation induced by a different irritant. According to our results, TFE $(200 \mathrm{mg} / \mathrm{kg})$ also showed significant effect against carrageenan-induced paw edema in mice model. From these two results, it is believed that TFE has potent antiinflammatory effects in mice with different irritate agents.

The effect of TFE on $P$. acnes plus LPS-induced liver inflammation was investigated as well. Liver inflammation evoked by intravenous injection of $P$. acnes plus LPS had been considered as experimentally induced chronic autoimmune active hepatitis $[29,30]$. Which can be indicated by the elevation of plasma ALT level [15]. When the mice were treated with TFE (50, 100, and $200 \mathrm{mg} / \mathrm{kg}$ ), the elevated plasma ALT activity was significantly decreased. We also found that
$P$. acnes plus LPS injection increased the levels of NO in liver. During inflammation, reactive oxygen species (ROS) produce high levels of NO to exert a defense against pathogens, but excess NO production is believed to act as a toxic radical, which was implicated in the etiology of inflammation and triggering several unfavorable responses [31]. ROS together with $\mathrm{NO}$, a reactive nitrogen species which is known to be involved in oxidative stress, will increase the production of proinflammatory cytokines such as TNF- $\alpha$ and IL-1 [32]. Elevated pro-inflammatory cytokines have been shown to play important pathogenic roles in liver inflammation [33]. In this study, TFE decreased the expressions of TNF- $\alpha$ and IL- $1 \beta$, these results suggested the protective effect of TFE on immunological liver inflammation by inhibiting the proinflammatory cytokines expression.

In conclusion, our results clearly indicated that tea flowers are rich in polyphenols and have potent antiinflammatory effects on acute inflammation and immunological liver inflammation in vivo. Mechanism studies suggested that the anti-inflammatory effects of TFE were associated with the suppression of $\mathrm{NO}$ production and the expression of TNF- $\alpha$ and IL- $1 \beta$ mRNA. These findings would be helpful to promote tea flower as a well-accepted healthy tea beverage.

\section{Conflict of Interest}

The authors declare no conflict of interest.

\section{Authors' Contribution}

B.-T. Chen and W.-X. Li contributed equally.

\section{Acknowledgments}

This work was supported by the State Key Laboratory of Drug Research (no. SIMM1106KF-13), Shanghai, China.

\section{References}

[1] H. N. Graham, "Green tea composition, consumption, and polyphenol chemistry," Preventive Medicine, vol. 21, no. 3, pp. 334-350, 1992.

[2] R. R. He, L. Chen, B. H. Lin, Y. Matsui, X. S. Yao, and H. Kurihara, "Beneficial effects of oolong tea consumption on diet-induced overweight and obese subjects," Chinese Journal of Integrative Medicine, vol. 15, no. 1, pp. 34-41, 2009.

[3] S. Gupta, K. Hastak, N. Ahmad, J. S. Lewin, and H. Mukhtar, "Inhibition of prostate carcinogenesis in TRAMP mice by oral infusion of green tea polyphenols," Proceedings of the National Academy of Sciences of the United States of America, vol. 98, no. 18, pp. 10350-10355, 2001.

[4] M. G. L. Hertog, E. J. M. Feskens, P. C. H. Hollman, M. B. Katan, and D. Kromhout, "Dietary antioxidant flavonoids and risk of coronary heart disease: the Zutphen Elderly Study," The Lancet, vol. 342, no. 8878, pp. 1007-1011, 1993.

[5] K. Yanagimoto, H. Ochi, K. G. Lee, and T. Shibamoto, "Antioxidative activities of volatile extracts from green tea, oolong tea, and black tea," Journal of Agricultural and Food Chemistry, vol. 51, no. 25, pp. 7396-7401, 2003. 
[6] S. M. Karori, R. M. Ngure, F. N. Wachira, J. K. Wanyoko, and J. N. Mwangi, "Different types of tea products attenuate inflammation induced in Trypanosoma brucei infected mice," Parasitology International, vol. 57, no. 3, pp. 325-333, 2008.

[7] Y. Levites, O. Weinreb, G. Maor, M. B. H. Youdim, and S. Mandel, "Green tea polyphenol (-)-epigallocatechin-3-gallate prevents N-methyl-4-phenyl- 1,2,3,6-tetrahydropyridine-induced dopaminergic neurodegeneration," Journal of Neurochemistry, vol. 78, no. 5, pp. 1073-1082, 2001.

[8] Y. S. Lin, S. S. Wu, and J. K. Lin, "Determination of tea polyphenols and caffeine in tea flowers (Camellia sinensis) and their hydroxyl radical scavenging and nitric oxide suppressing effects," Journal of Agricultural and Food Chemistry, vol. 51, no. 4, pp. 975-980, 2003.

[9] T. D. Way, H. Y. Lin, K. T. Hua et al., "Beneficial effects of different tea flowers against human breast cancer MCF-7 cells," Food Chemistry, vol. 114, no. 4, pp. 1231-1236, 2009.

[10] H. Kurihara, H. Shibata, Y. Fukui et al., "Evaluation of the hypolipemic property of Camellia sinensis var. ptilophylla on postprandial hypertriglyceridemia," Journal of Agricultural and Food Chemistry, vol. 54, no. 14, pp. 4977-4981, 2006.

[11] L. C. Wu, A. F. J. Jou, S. H. Chen et al., "Antioxidant, antiinflammatory and anti-browning activities of hot water extracts of oriental herbal teas," Food and Function, vol. 1, no. 2, pp. 200-208, 2010.

[12] L. Bao, X. Yao, J. Xu, X. Guo, H. Liu, and H. Kurihara, "Effects of Pithecellobium clypearia Benth extract and its main components on inflammation and allergy," Fitoterapia, vol. 80, no. 6, pp. 349-353, 2009.

[13] N. Garbacki, V. Gloaguen, J. Damas, P. Bodart, M. Tits, and L. Angenot, "Anti-inflammatory and immunological effects of Centaurea cyanus flower- heads," Journal of Ethnopharmacology, vol. 68, no. 1-3, pp. 235-241, 1999.

[14] C. A. Winter, E. A. Risley, and G. W. Nuss, "Carrageenininduced edema in hind paw of the rat as an assay for antiiflammatory drugs," Proceedings of the Society for Experimental Biology and Medicine, vol. 111, pp. 544-547, 1962.

[15] H. Kurihara, H. Fukami, S. Asami et al., "Influence of histamine in a liver injury model induced by Propionibacterium acnes and lipopolysaccharide," Biological and Pharmaceutical Bulletin, vol. 26, no. 10, pp. 1393-1397, 2003.

[16] R. Guler, M. L. Olleros, D. Vesin et al., "Inhibition of inducible nitric oxide synthase protects against liver injury induced by mycobacterial infection and endotoxins," Journal of Hepatology, vol. 41, no. 5, pp. 773-781, 2004.

[17] P. Rishi, S. K. Mavi, S. Bharrhan, G. Shukla, and R. Tewari, "Protective efficacy of probiotic alone or in conjunction with a prebiotic in Salmonella-induced liver damage," FEMS Microbiology Ecology, vol. 69, no. 2, pp. 222-230, 2009.

[18] S. J. Duffy, J. F. Keaney, M. Holbrook et al., "Short- and longterm black tea consumption reverses endothelial dysfunction in patients with coronary artery disease," Circulation, vol. 104, no. 2, pp. 151-156, 2001.

[19] A. Steptoe, E. L. Gibson, R. Vuononvirta et al., "The effects of chronic tea intake on platelet activation and inflammation: a double-blind placebo controlled trial," Atherosclerosis, vol. 193, no. 2, pp. 277-282, 2007.

[20] C. S. Yang and J. M. Landau, "Effects of tea consumption nutrition health," Journal of Nutrition, vol. 130, no. 10, pp. 2409-2412, 2000.

[21] Z. Yang, Y. Tu, S. Baldermann, F. Dong, Y. Xu, and N. Watanabe, "Isolation and identification of compounds from the ethanolic extract of flowers of the tea (Camellia sinensis) plant and their contribution to the antioxidant capacity,"
LWT-Food Science and Technology, vol. 42, no. 8, pp. 14391443, 2009.

[22] M. Gábor, "Models of acute inflammation in the ear," Methods in Molecular Biology (Clifton, N.J.), vol. 225, pp. 129-137, 2003.

[23] R. A. Saraiva, M. K. A. Araruna, R. C. Oliveira et al., "Topical anti-inflammatory effect of Caryocar coriaceum Wittm. (Caryocaraceae) fruit pulp fixed oil on mice ear edema induced by different irritant agents," Journal of Ethnopharmacology, vol. 136, no. 3, pp. 504-510, 2011.

[24] T. S. Rao, J. L. Currie, A. F. Shaffer, and P. C. Isakson, "Comparative evaluation of arachidonic acid (AA)- and tetradecanoylphorbol acetate (TPA)-induced dermal inflammation," Inflammation, vol. 17, no. 6, pp. 723-741, 1993.

[25] G. Furstenberger, B. I. Csuk-Glanzer, F. Marks, and D. Keppler, "Phorbol ester-induced leukotriene biosynthesis and tumor promotion in mouse epidermis," Carcinogenesis, vol. 15, no. 12, pp. 2823-2827, 1994.

[26] J. Hong, T. J. Smith, C. T. Ho, D. A. August, and C. S. Yang, "Effects of purified green and black tea polyphenols on cyclooxygenase- and lipoxygenase-dependent metabolism of arachidonic acid in human colon mucosa and colon tumor tissues," Biochemical Pharmacology, vol. 62, no. 9, pp. 11751183, 2001.

[27] J. H. Yoon and S. J. Baek, "Molecular targets of dietary polyphenols with anti-inflammatory properties," Yonsei Medical Journal, vol. 46, no. 5, pp. 585-596, 2005.

[28] S. Y. Schubert, E. P. Lansky, and I. Neeman, "Antioxidant and eicosanoid enzyme inhibition properties of pomegranate seed oil and fermented juice flavonoids," Journal of Ethnopharmacology, vol. 66, no. 1, pp. 11-17, 1999.

[29] S. Wasaki, I. Sakaida, K. Uchida, T. Kimura, K. Kayano, and K. Okita, "Preventive effect of cyclosporin A on experimentally induced acute liver injury in rats," Liver, vol. 17, no. 2, pp. 107114, 1997.

[30] K. Matsui, T. Yoshimoto, H. Tsutsui et al., "Propionibacterium acnes treatment diminishes CD4+ NK1.1+ T cells but induces type I T cells in the liver by induction of IL-12 and IL-18 production from Kupffer cells," Journal of Immunology, vol. 159, no. 1, pp. 97-106, 1997.

[31] M. M. Y. Chan, D. Fong, C. T. Ho, and H. I. Huang, "Inhibition of inducible nitric oxide synthase gene expression and enzyme activity by epigallocatechin gallate, a natural product from green tea," Biochemical Pharmacology, vol. 54, no. 12, pp. 1281-1286, 1997.

[32] K. Yamamoto, R. Kushima, O. Kisaki, Y. Fujiyama, and H. Okabe, "Combined effect of hydrogen peroxide induced oxidative stress and IL- $1 \alpha$ on IL- 8 production in $\mathrm{CaCo}-2$ cells (a human colon carcinoma cell line) and normal intestinal epithelial cells," Inflammation, vol. 27, no. 3, pp. 123-128, 2003.

[33] S. Kamimura and H. Tsukamoto, "Cytokine gene expression by Kupffer cells in experimental alcoholic liver disease," Hepatology, vol. 22, no. 4, pp. 1304-1309, 1995. 


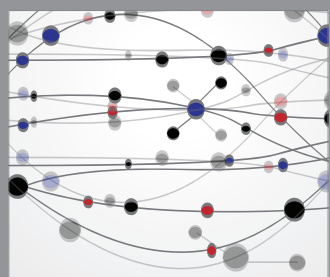

The Scientific World Journal
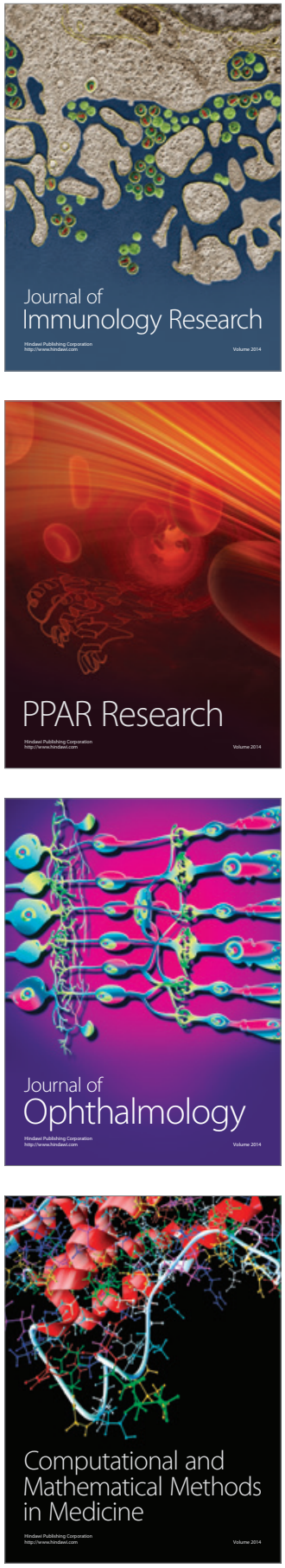

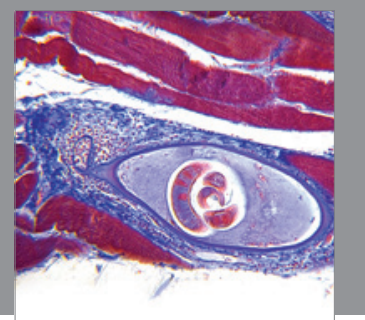

Gastroenterology

Research and Practice
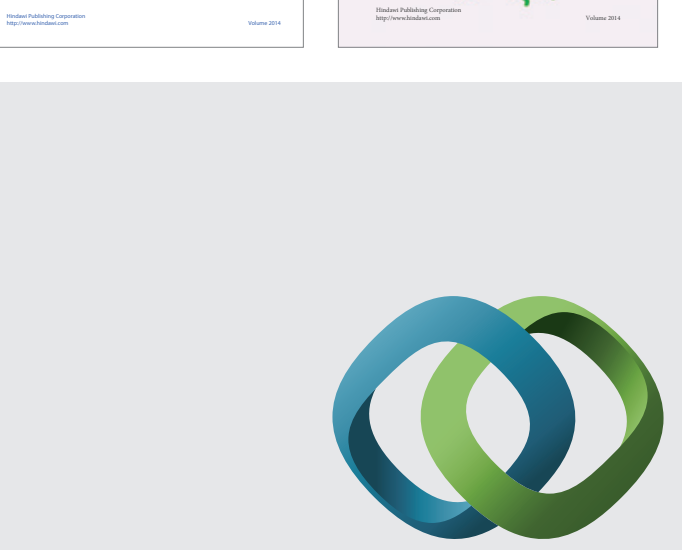

\section{Hindawi}

Submit your manuscripts at

http://www.hindawi.com
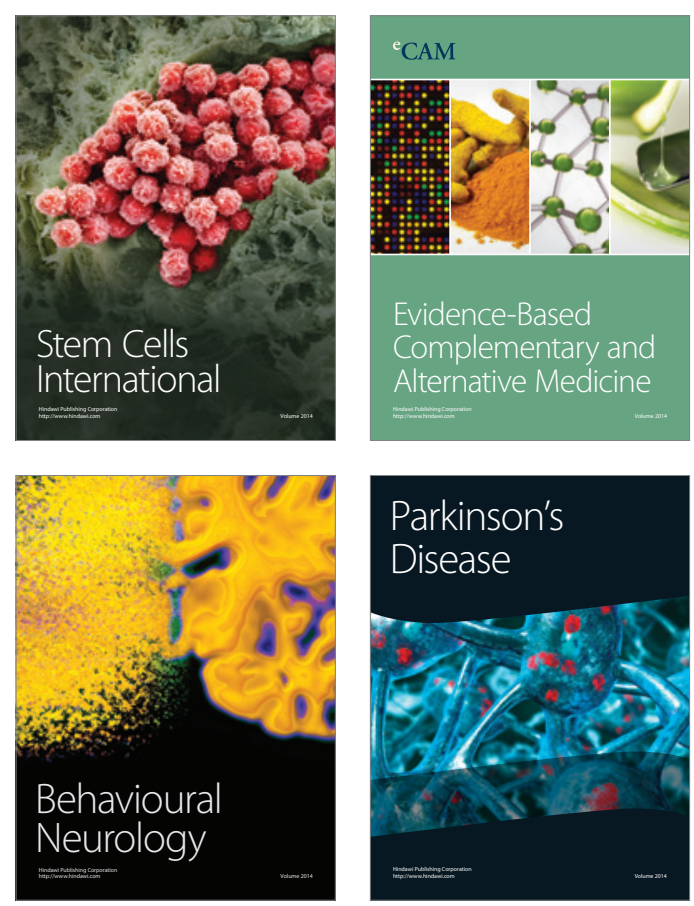

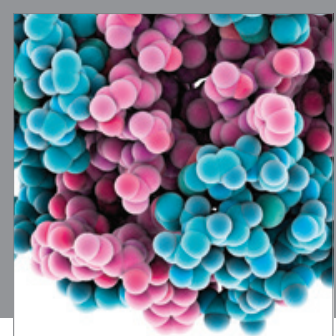

Journal of
Diabetes Research

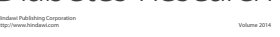

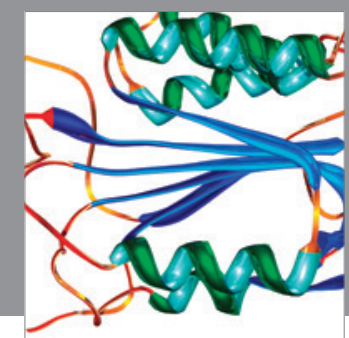

Disease Markers
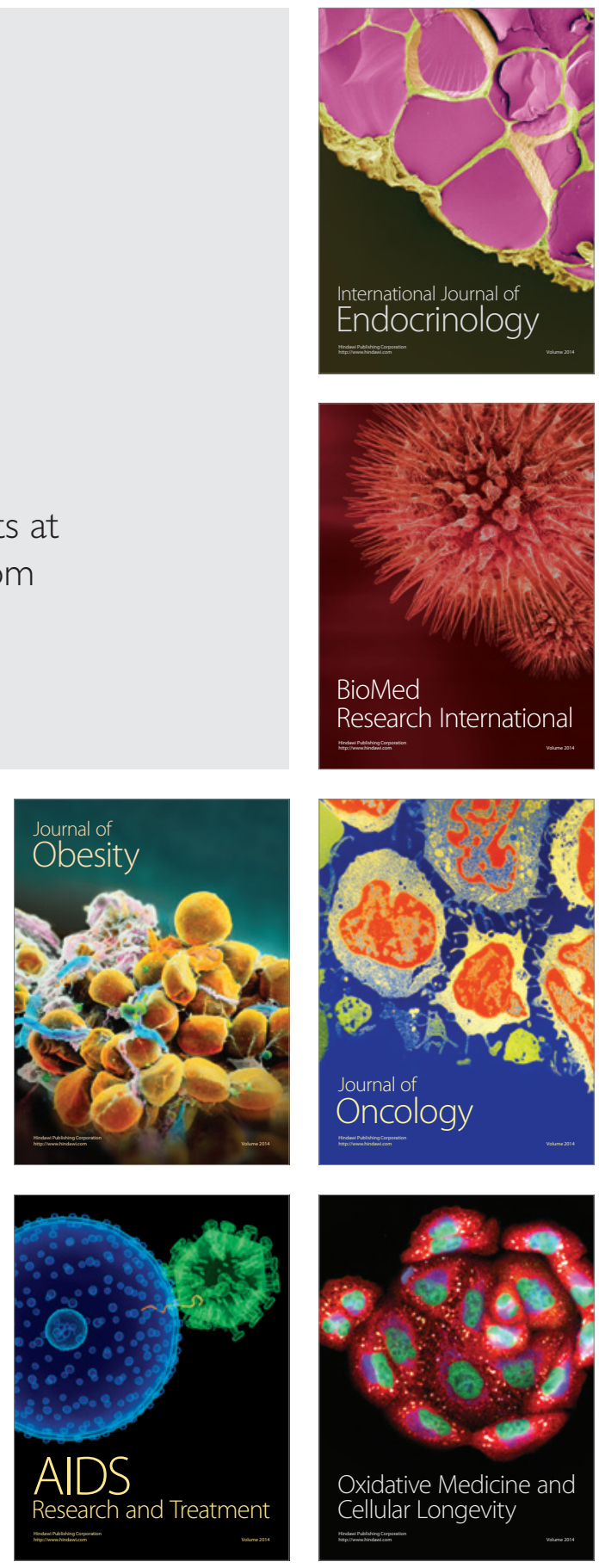